\title{
ANALISIS PEAK GROUND ACCELERATION (PGA) KOTA TEGAL MENGGUNAKAN METODE HVSR (HORIZONTAL TO VERTICAL SPECTRA RATIO)
}

\author{
Nia Annisa Ferani Tanjung ${ }^{1,{ }^{*}}$, Indah Permatasari ${ }^{2}$, Abdul Hakim Prima Yuniarto ${ }^{3}$ \\ ${ }^{1}$ Program Studi S1 Rekayasa Perangkat Lunak, Fakultas Informatika, Institut Teknologi Telkom Purwokerto \\ ${ }^{2}$ Program Studi S1 Teknik Telekomunikasi, Fakultas Teknik Telekomunikasi dan Elektro, Intitut Teknologi Telkom \\ Purwokerto \\ ${ }^{3}$ Program Studi Fisika, Fakultas Sains dan Teknologi, Institut Teknologi dan Sains Nahdlatul Ulama Pekalongan \\ *Penulis Korespondensi : nia@ittelkom-pwt.ac.id
}

\begin{abstract}
Abstrak. Seismisitas Kota Tegal dipengaruhi oleh keberadaan segmen sesar Baribis-Kendeng yang melewati Kota Tegal dengan kecepatan rata-rata 4,5 mm/tahun. Kota Tegal merupakan kota yang sedang berkembang, sehingga mikrozonasi kegempaan perlu dilakukan untuk mendukung tata letak pembangunan di Kota Tegal. Mikrozonasi dilakukan dengan menganalisis nilai dari PGA (Peak Ground Acceleration) data mikrotremor di 37 titik di Kota Tegal. Metode yang digunakan untuk mengolah data adalah metode HVSR (Horizontal to Vertical Spectral Ratio) sehingga didapatkan nilai frekuensi dominan (fo) dan amplifikasi $(A o)$ pada daerah penelitian. Metode Kanai digunakan untuk menganalisis nilai PGA (Peak Ground Acceleration) dan didapatkan nilai PGA di Kota Tegal mulai dari 5,88 - 27,59 gal. Hal ini menyatakan bahwa tingkat risiko gempabumi di Kota Tegal adalah sangat kecil hingga tingkat risiko kecil. Kata Kunci: Kota Tegal; HVSR; PGA; Kanai
\end{abstract}

\begin{abstract}
The seismicity of the Tegal City is influenced by the presence of the Baribis-Kendeng fault segment passing through the city of Tegal with an average speed of $4.5 \mathrm{~mm} /$ year. Tegal City is a developing city, so the microzonation of seismicity needs to be done to support the development layout in Tegal City. Microzonation is carried out by analyzing the value of the PGA (Peak Ground Acceleration) microtremor data at 37 points in Tegal City. The method used to process the data was the HVSR (Horizontal to Vertical Spectral Ratio) method so that the dominant frequency (fo) and amplification (Ao) values are obtained in the study area. The Kanai method was used to analyze the PGA (Peak Ground Acceleration) value and the PGA values in Tegal City were obtained from $5.88-27.59$ gal. This shows that the level of earthquake risk in Tegal City ranges from very small to small.
\end{abstract}

Keywords: Tegal City; HVSR; PGA; Kanai

\section{PENDAHULUAN}

Proses subduksi yang terjadi pada Lempeng Indo-Australia yang mendorong Tatanan Blok Sunda di selatan Pulau Jawa mengakibatkan kondisi geodinamika yang tinggi di Pulau Jawa sehingga terbentuk regional daratan Jawa yang dapat dilihat melalui pola sesar. Pola-pola sesar tersebut berkontribusi terhadap gempa-gempa dangkal yang terjadi di Pulau Jawa (Ilahi, 2018). Sesar BaribisKendeng merupakan sesar naik yang diketahui aktif sejak periode Neogen Akhir hingga sekarang. Pola sesar Baribis-Kendeng dapat ditelusuri dari barat hingga timur di bagian utara pulau Jawa (Simandjutak, 1993). Melalui observasi GPS, diketahui bahwa pergerakan sesar Baribis-Kendeng sebesar 0,2 - $5 \mathrm{~mm}$ /tahun (Koulali dkk., 2016). Sesar ini merupakan sesar aktif yang menyebabkan beberapa kerusakan seperti gempa Karawang 1862, gempa Kuningan 1842, gempa Majalengka 1912, dan gempa Madiun 2016 (Nguyen dkk., 2015; Sari dan Subakti, 2015).

Wilayah Pantura Barat mempunyai beberapa sesar. Sesar-sesar tersebut berupa patahan lempengan yang terletak di Cirebon, Brebes, Pemalang, dan Pekalongan. Tiga sesar diantaranya menghimpit wilayah Kota dan Kabupaten Tegal yaitu Sesar Baribis-Kendeng Cirebon dengan kecepatan gerak $(0,5 \mathrm{~mm} /$ tahun), Sesar BaribisKendeng Brebes yang bergerak sekitar $(4,5$ $\mathrm{mm} /$ tahun), dan Sesar Baribis-Kendeng Pemalang dengan kecepatan gerak (4,5 mm/tahun) (Gumilang, 2018). Wilayah Tegal sendiri dilalui oleh Sesar 
Baribis-Kendeng Tegal (4,5 mm/tahun) dengan kedudukan Strike ENE dan Dip 45S (Tim Pusat Studi Gempa Nasional, 2017). Hal ini menyebabkan Kota Tegal menjadi kota yang rawan terkena aktivitas gempa bumi.

Berdasarkan Peta Geologi Lembar Purwokerto dan Tegal, Kota Tegal tersusun atas endapan sungai dan pantai dengan ketebalan hingga 150 meter. endapan ini tersusun atas kerikil, pasir, lanau dan lempung yang merupakan batuan aluvium (Djuri dkk., 1996). Kerusakan yang diakibatkan oleh gempa, tidak hanya dipengaruhi oleh besarnya kekuatan gempa. Akan tetapi kerusakan juga dipengaruhi oleh kondisi geologi suatu wilayah (Daryono dkk., 2009). Daerah rawan kerusakan akibat gempa bumi terjadi pada daerah sedimen lunak tebal yang berada di atas bedrock yang keras (Wulandari dkk., 2018). Semakin labil (lunak) batuan penyusun suatu wilayah, maka semakin besar pula efek gempa bumi yang akan terjadi di kawasan tersebut. Hal ini dikarenakan wilayah yang labil mempunyai sifat batuan yang umumnya belum kompak, sehingga mudah terurai dan jika terjadi gempa, maka kerusakan akibat gempa akan semakin besar (Supartoyo dkk., 2009).

Berdasarkan hal-hal yang telah diuraikan di atas, maka perlu adanya pemetaan daerah rawan bencana gempa di Kota Tegal, melihat tingginya aktivitas seismik, batuan penyusun, dan ketebalan lapisan sedimennya. Pemanfaatan gelombang mikroseismik alami suatu daerah dapat menggambarkan kondisi bawah permukaannya. Dengan menggunakan metode HVSR, akan didapatkan parameter-parameter karakteristik bawah permukaan berupa frekuensi natural $(f o)$ dan amplifikasi $(A o)$. Data yang didapat kemudian diolah untuk memetakan Peak Ground Acceleration (PGA) daerah Kota Tegal.

\section{METODOLOGI}

Penelitian dimulai dari studi kajian geologi mengenai sesar Baribis-Kendeng dan Kota Tegal, serta studi pustaka mengenai metode HVSR dan metode Kanai. Penelitian dilanjutkan dengan melakukan akuisisi data, pengolahan, hingga menarik kesimpulan. Diagram alir penelitian yang menggambarkan alur penelitian dapat dilihat pada Gambar 1.

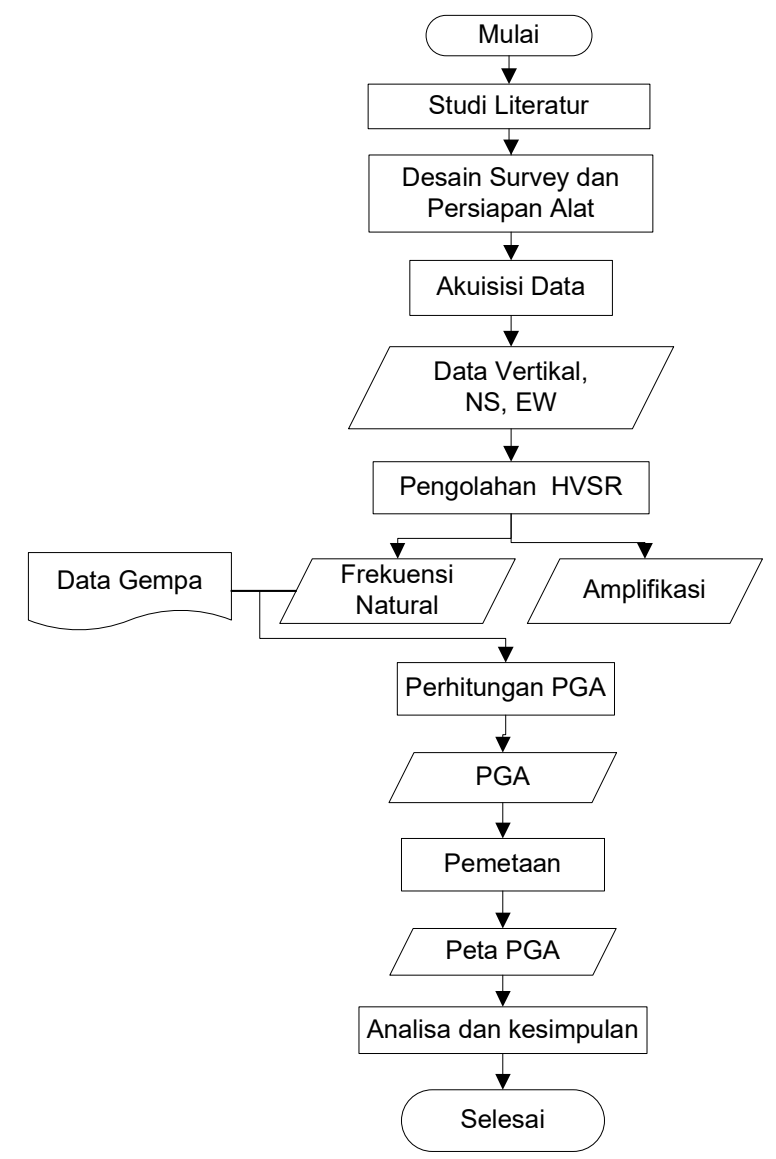

Gambar 1. Diagram alir penelitian

Pengukuran mikroseismik dilakukan di 37 titik di Kota Tegal dengan spasi antar titik sekitar $\pm 1 \mathrm{~km}$ dengan menggunakan seismometer LE-3D lite 3 komponen (Vertikal, Utara-Selatan, Barat-Timur). Durasi pengambilan data di setiap titik bervariasi sekitar 30-45 menit. Gambar 2 merupakan peta titik-titik survei mikroseismik yang dilakukan di Kota Tegal.

Data yang terekam disimpan dalam bentuk format MSD. Data lalu diolah dengan menggunakan metode HVSR pada Software Geopsy. Nogoshi dan Igarashi (1971) memperkenalkan metode ini untuk pertama kali dan disempurnakan oleh Nakamura (1989), yang menyatakan bahwa fungsi site transfer untuk gelombang $\mathrm{S}$ lapisan permukaan berhubungan erat dengan perbandingan spektrum komponen horizontal dan vertikalnya $(H / V)$. 


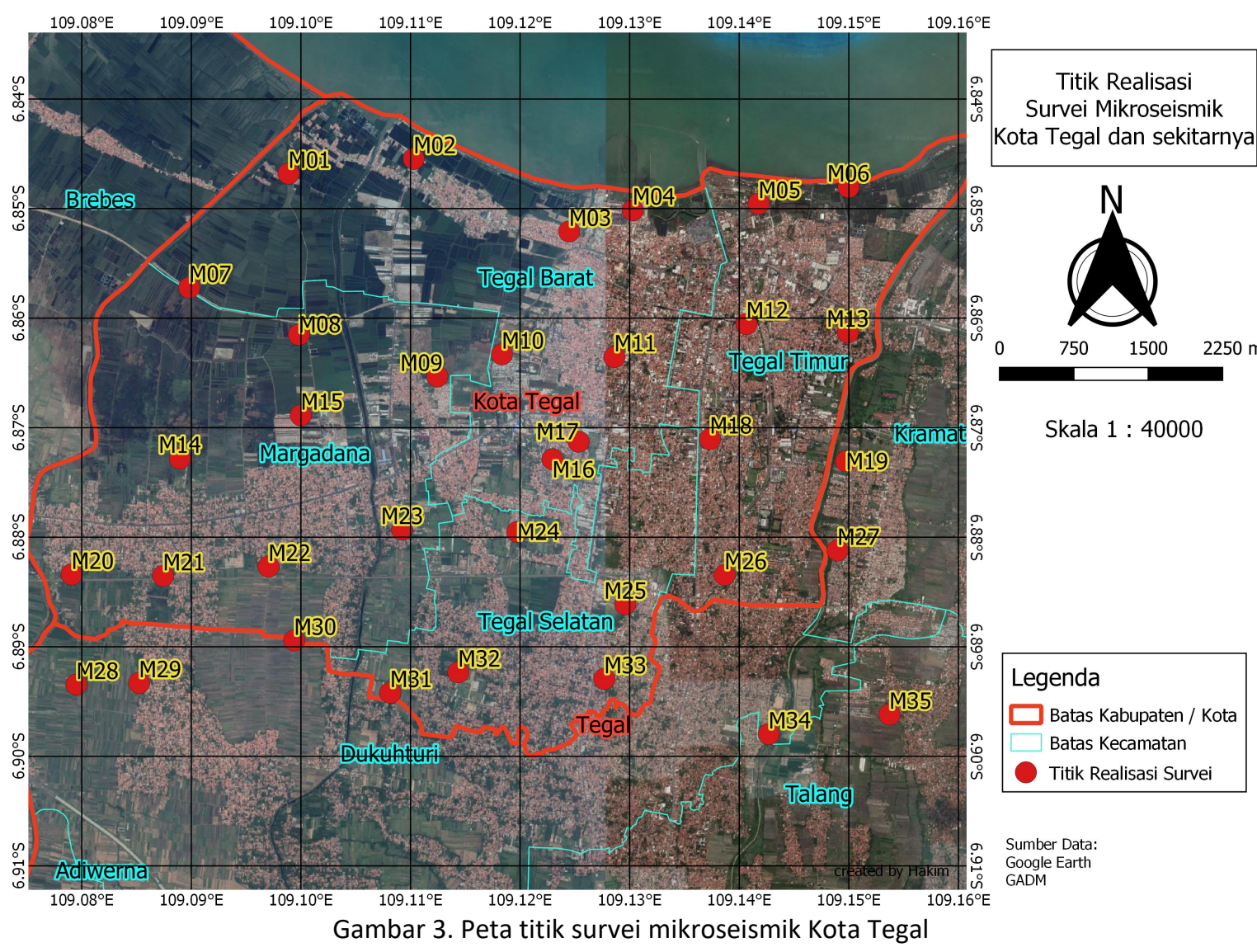

Analisis spektral $\mathrm{H} / \mathrm{V}$ tiga komponen sinyal yang terekam (Vertikal, Utara-Selatan, Barat-Timur) diolah dengan menggunakan software Geopsy. Setelah data diinput kemudian dilakukan proses windowing sehingga semua event transient dapat dihilangkan. Hasil analisis HVSR menunjukkan suatu

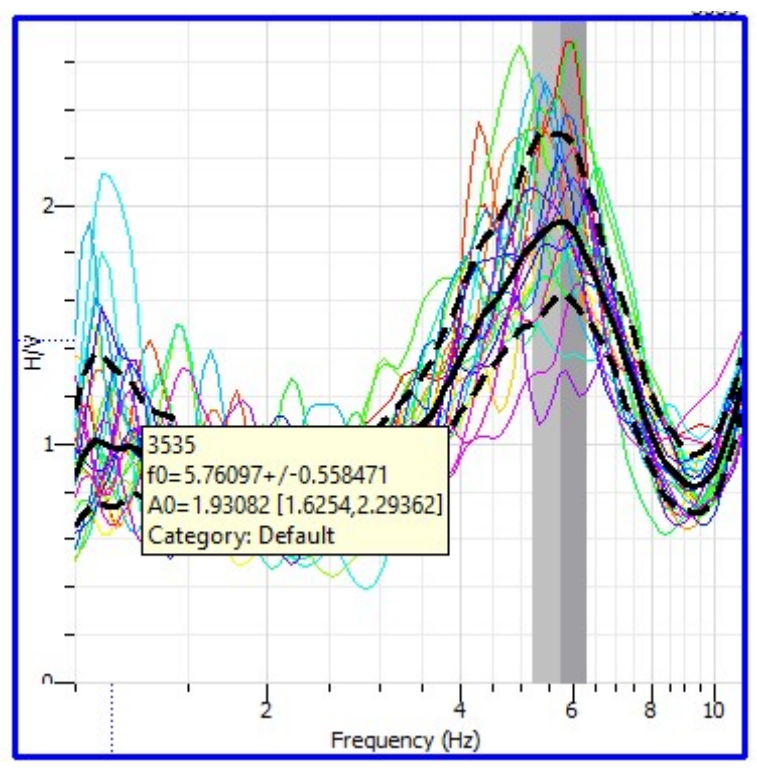

Gambar 2 Kurva H/V titik pengukuran M26 puncak spektrum yang berada pada frekuensi predominan (Nakamura, 1989). Hal ini ditunjukkan pada Gambar 3, dimana terlihat nilai amplifikasi (Ao) dan frekuensi natural (fo) daerah penelitian pada titik M26.

Nilai frekuensi natural yang telah didapatkan dari kurva $\mathrm{H} / \mathrm{V}$ digunakan dalam proses penghitungan percepatan getaran tanah maksimum atau Peak Ground Acceleration (PGA). Percepatan Getaran Tanah Maksimum yang diakibatkan oleh gempabumi merupakan percepatan getaran tanah paling besar yang pernah terjadi pada suatu titik pada area tertentu dalam suatu kawasan. Percepatan ini dihitung berdasarkan pengaruh semua gempabumi yang pernah terjadi pada kurun waktu tertentu. Hal ini dihitung dengan meninjau besarnya magnitudo dan jarak hiposenter gempa, serta periode dominan tanah di mana titik tersebut berada. Perhitungan nilai dari PGA di titik pengukuran menggunakan formulasi (Kanai, 1996) sebagai berikut: 
$\mathrm{a}_{0}=\frac{1}{\mathrm{~T}_{0}} 10^{(0,651 \mathrm{M})-\left(1,66+\frac{3,6}{\mathrm{R}}\right) \log \mathrm{R}+\left(0,167-\frac{1,83}{\mathrm{R}}\right)}$

dengan To adalah nilai periode dominan yang didapat dari $1 /$ fo, besar magnitudo dari gempa dilambangkan dengan $M$, dan jarak dari hiposenter ke titik pengukuran disimbolkan dengan $R$. Data gempa yang dipakai dalam mengukur PGA bersumber dari data gempa yang pernah terjadi di sekitar Jawa Tengah dengan Magnitudo 6 SR.

\section{HASIL DAN PEMBAHASAN}

\section{Frekuensi Natural (fo) dan Amplifikasi (Ao)}

Nilai frekuensi natural dan amplifikasi di suatu permukaan, menggambarkan karakteristik bawah permukaan daerah penelitian (Herak, 2008). Pada daerah penelitian, nilai frekuensi natural yang didapat sekitar 0,62 Hz-12, $81 \mathrm{~Hz}$. Hal ini dipetakan pada Gambar 4.

Nilai frekuensi natural tinggi terlihat di beberapa titik di Kota Tegal. Hal tersebut dapat dilihat pada kecamatan Margadana bagian barat, Tegal barat bagian timur laut, dan nilai frekuensi natural tertinggi terlihat pada Kecamatan Tegal timur bagian selatan dengan nilai frekuensi natural $12,81 \mathrm{~Hz}$. Pada pusat Kota Tegal, terlihat nilai frekuensi natural yang rendah, yaitu sekitar $0,62 \mathrm{~Hz}$ $-1 \mathrm{~Hz}$.

Gambar 5 menunjukkan hasil pengukuran di 37 Titik pengukuran di Kota Tegal mendapatkan nilai amplifikasi yang bervariasi yaitu mulai dari 0,80 6,70. Nilai amplifikasi tertinggi terlihat pada Kecamatan Margadana bagian barat yaitu 6,70. Nilai amplifikasi ini berpengaruh terhadap penguatan gelombang ketika melewati suatu medium penghantar. Semakin besar nilai amplifikasi, maka semakin besar pula potensi kerusakan saat terjadi gempa, pun sebaliknya (Tanjung dkk., 2019). Setiawan (2009) mengklasifikasian suatu daerah berdasarkan nilai amplifikasi daerahnya yang ditampilkan pada Tabel 1.

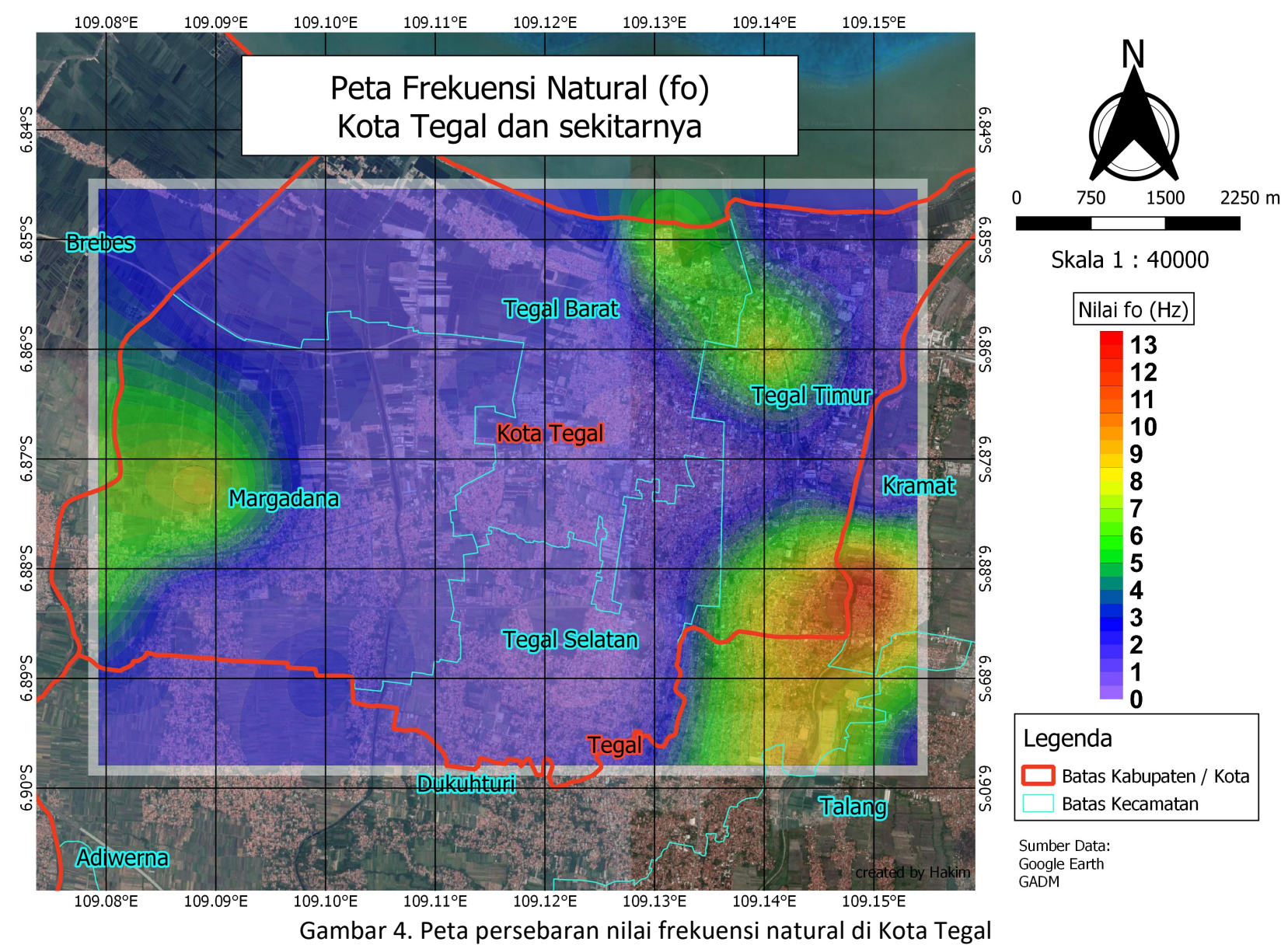




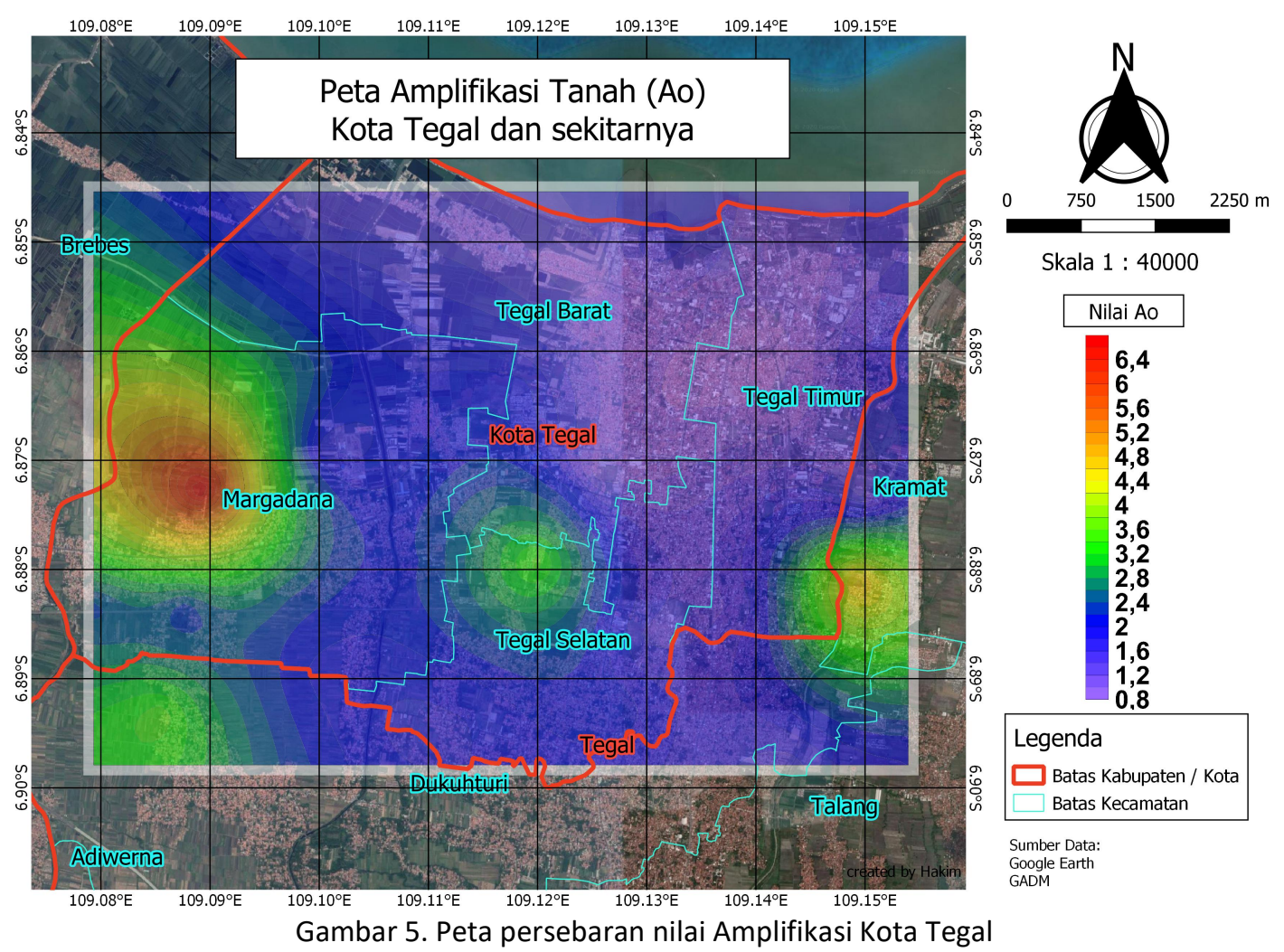

Berdasarkan Tabel 1, Kecamatan Margadana masuk ke zona 3 dengan klasifikasi amplifikasi tinggi, sedangkan untuk kecamatan lainnya masuk ke zona 1 dan 2 yaitu kawasan dengan klasifikasi amplifikasi rendah dan sedang.

Tabel 1. Klasifikasi nilai amplifikasi (Setiawan, 2009)

\begin{tabular}{ccc}
\hline Zona & Klasifikasi & Nilai Faktor Amplifikasi \\
\hline 1 & Rendah & Ao $<3$ \\
2 & Sedang & $3 \leq$ Ao $<6$ \\
3 & Tinggi & $6 \leq$ Ao $<9$ \\
4 & Sangat Tinggi & Ao $\geq 9$ \\
\hline
\end{tabular}

\section{Peak Ground Acceleration (PGA)}

Percepatan tanah maksimum (PGA) yaitu besarnya percepatan gerak tanah paling kuat yang pernah terjadi di suatu area. Hal ini terjadi ketika nilai frekuensi natural suatu daerah sama dengan nilai frekuensi seismik gempa yang datang (Ozaki dkk., 1977). Berdasarkan data hasil pengukuran di 37 titik di Kota Tegal, didapatkan nilai PGA di kawasan Tegal berkisar 5,88 gal - 27, 59 gal. Hal ini dapat dilihat pada Gambar 6 .

Persebaran nilai PGA di Kota Tegal yang terlihat pada Gambar 6 bahwa nilai PGA di Kota Tegal bervariasi. Berdasarkan tingkat risiko gempabumi yang dapat dilihat pada Tabel 2, maka kawasan Tegal dan sekitarnya dapat dikategorikan berada pada tingkat risiko gempabumi sangat kecil hingga kecil.

Pada Kecamatan Margadana sebelah barat memiliki nilai PGA yang lebih tinggi dibandingkan dengan bagian timurnya. Pada Kecamatan Tegal Selatan, terlihat nilai PGA yang rendah di seluruh area Tegal Selatan. Pada Kecamatan Tegal Timur bagian Utara dan selatan memiliki nilai PGA yang tinggi. Pada Kecamatan Tegal Barat terlihat nilai PGA yang rendah kecuali pada bagian Timur laut.

Berdasarkan pemetaan persebaran nilai frekuensi natural ( $f o$ ), amplifikasi $(A o)$ dan nilai Peak Ground Acceleration di Kota Tegal, dapat terlihat bahwa daerah yang memiliki kerentanan kecil ketika terjadi gempa bumi yaitu bagian barat Kecamatan Margadana, dan bagian tenggara Kecamatan Tegal Timur. Berdasarkan hasil penelitian yang telah diperoleh, daerah tersebut dikategorikan dalam instrumental intensity skala $\mathrm{V}$ yang jika terjadi gempa maka akan terasa cukup kuat. 


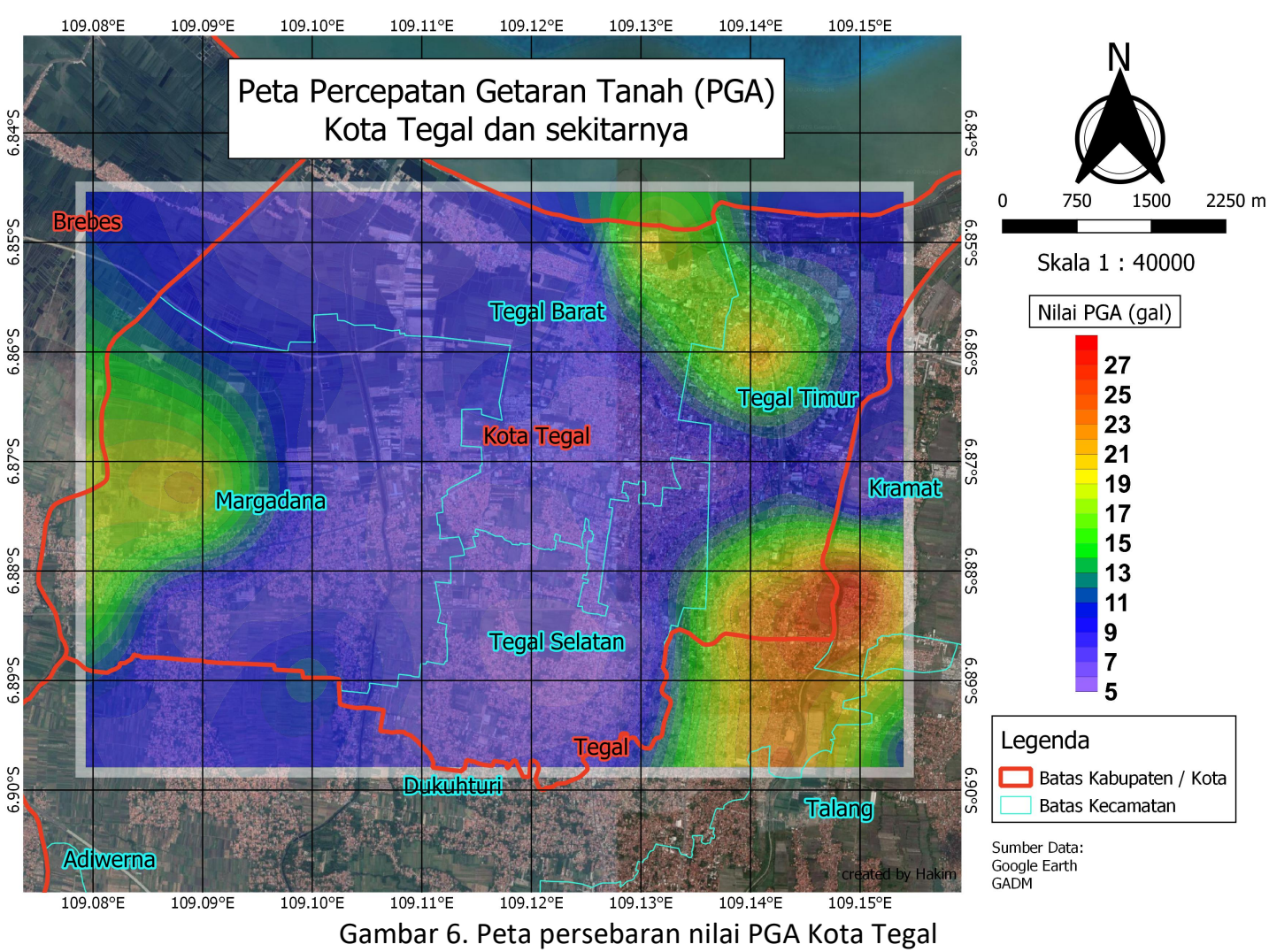

Tabel 2. Tingkat risiko gempabumi (Widyawarman, 2018)

\begin{tabular}{clc}
\hline No & \multicolumn{1}{|c}{ Tingkat Risiko } & $\begin{array}{c}\text { Nilai PGA } \\
\text { (gal) }\end{array}$ \\
\hline 1 & Risiko sangat kecil & $<25$ \\
2 & Risiko kecil & $25-50$ \\
3 & Risiko sedang satu & $50-75$ \\
4 & Risiko sedang dua & $75-100$ \\
5 & Risiko sedang tiga & $100-125$ \\
6 & Risiko besar satu & $125-150$ \\
7 & Risiko besar dua & $150-200$ \\
8 & Risiko besar tiga & $200-300$ \\
9 & Risiko sangat besar & $300-600$ \\
& satu & $>600$ \\
10 & Risiko sangat besar & \\
& dua & \\
\hline
\end{tabular}

\section{PENUTUP}

\section{Simpulan}

Berdasarkan penelitian yang telah dilakukan, kesimpulan yang dapat diambil dari penelitian ini adalah nilai PGA di kawasan Tegal berkisar antara 5,88 gal - 27,59 gal. Hal ini menyatakan bahwa tingkat risiko gempabumi di Kota Tegal adalah sangat kecil hingga tingkat risiko kecil.

\section{Saran}

Saran yang dapat diberikan untuk membangun hipotesa bagi para peneliti selanjutnya adalah :

1. Perlu pengembangan penelitian pada daerah yang teridentifikasi memiliki nilai-nilai parameter kerentanan gempa, yaitu kecamatan Margadana dan Tegal Timur.

2. Perlu dilakukan pemodelan bawah permukaan di Kecamatan Margadana karena terlihat perbedaan kontras yang sangat jelas pada nilai fo, Ao, dan PGA di bagian barat dan timurnya.

\section{Ucapan Terima Kasih}

Penulis menyampaikan ucapan terimakasih pada Ristekdikti karena telah membiayai seluruh penelitian. Penulis juga menyampaikan terimakasih kepada Bappeda dan BPBD Kota Tegal yang telah memberikan izin selama pengambilan data di Kota Tegal, serta kepada seluruh civitas akademik di lingkungan IT Telkom Purwokerto dalam dukungan selama penyelesaian tulisan ini. 


\section{DAFTAR PUSTAKA}

Daryono, Sutikno, Sartohadi, J., Dulbahri dan Brotopuspito, K.S. (2009), "Pengkajian Local Site Effect Di Graben Bantul Menggunakan Indeks Kerent Anan Seismik Berdasarkan Pengukuran Mikrotremor", Jurnal Kebencanan Indonesia, Vol.2, No.1, hal. 456-467.

Djuri, M., Samodra, H., Amin, T.C. dan Gafoer, S. (1996), Peta Geologi Lembar Purwokerto dan Tegal, Jawa Pusat Penelitian dan Pengembangan Geologi,.

Gumilang, A. (2018), "Meski Terdapat Sesar Patahan Lempeng,Wilayah Pantura Barat Jateng Masih Aman". Jateng News. Diambil dari http://jateng.news/berita/detail/1533718477/69158 3/patahan-lempengan-di-pantura-barat-aktifpotensi-gempa-muncul-di-tegal-brebes-danpemalang/85359874457.

Herak, M. (2008), "ModelHVSR-A Matlab ${ }^{\circledR}$ Tool to Model Horizontal-to-Vertical Spectral Ratio of Ambient Noise", Computers \& Geosciences, Vol.34, No.11, hal. 1514-1526. http://doi.org/10.1016/j.cageo.2007.07.009.

Ilahi, R. (2018), Analisis Deformasi Stasiun CORS BIG di Sekitar Sesar Baribis dan Anjak Kendeng Berdasarkan Data Pengamatan Multi Tahun (2015, 2016, 2017), Skripsi, Universitas Gadjah Mada, Yogyakarta. Diambil dari http://etd.repository.ugm.ac.id/penelitian/detail/16 0161.

Kanai, K. (1996), "Improved Empirical formula for Characteristics of Stray (Sic) Earthquake Motions", Proceedings of the Japanese Earthquake, hal. 1-4,.

Koulali, A., McClusky, S., Susilo, S., Leonard, Y., Cummins, P., Tregoning, P., Meilano, I., Efendi, J. dan Wijanarto, A.B. (2016), "The Kinematics of Crustal Deformation in Java from GPS Observations: Implications for Fault Slip Partitioning", Earth and Planetary Science Letters, Vol.458, hal. 69-79. http://doi.org/10.1016/j.epsl.2016.10.039.

Nakamura, Y. (1989), "A Method for Dynamic Characteristics Estimation of Subsurface Using Microtremor on The Ground Surface", Quarterly Report of Railway Technical Research, Vol.30, No.1, hal. 25-33.
Nguyen, N., Griffin, J., Cipta, A. dan Cummins, P. (2015), Indonesia's Historical Earthquakes Modelled Examples for Improving The National Hazard Map, Geoscience Australia, Canberra. http://doi.org/10.11636/Record.2015.023.

Nogoshi, M. dan Igarashi, T. (1971), "On the Amplitude Characteristics of Microtremor (Part 2)", Journal of the Seismological Society of Japan, Vol.24, hal. 2640. http://doi.org/10.4294/ZISIN1948.24.1_26.

Ozaki, M., Kitagawa dan Hattori, S. (1977), "Study on Regional Distribution of Maximum Eartquake Motions in Japan", Wind and Seismic Effects: Proceedings of the Ninth Joint Panel Conference of the U.S.-Japan Cooperative Program in Natural Resources, Dept. of Commerce, National Bureau of Standards, Tokyo: Washington : U.S, hal. V14-V44,.

Sari, E.P. dan Subakti, H. (2015), "Identification of Baribis Fault - West Java Using Second Vertical Derivative Method of Gravity", AIP Conference Proceedings, Vol.1658, No.1, hal. 030016. http://doi.org/10.1063/1.4915024.

Setiawan, J. (2009), Mikrozonasi Seismisitas Daerah Yogyakarta dan Sekitarnya, Institut Teknologi Bandung, Bandung.

Simandjutak, T. (1993), "Neogene Tectonics and Oregenesis of Indonesia", dalam Geology Society of Malaysia, Circum-Pasific Council for Energy and Mineral Resources Tectonic Framework and Energy Resources of The Western Margin of the Pasific Basin, Kuala Lumpur, hal. 43-64.

Supartoyo, Sadisun, I.A. dan Abdullah, C.I. (2009), "Bencana Gempabumi di Indonesia Tahun 2008", Bulletin Vulkanologi dan Bencana Geologi, Vol.4, No.1, hal. 13-22.

Tanjung, N.A.F., Yuniarto, H.P. dan Widyawarman, D. (2019), "Analisis Amplifikasi dan Indeks Kerentanan Seismik di Kawasan Fmipa Ugm Menggunakan Metode HVSR", Jurnal Geosaintek, Vol.5, No.2, hal. 61-68.

http://doi.org/10.12962/j25023659.v5i2.5726.

Tim Pusat Studi Gempa Nasional (2017), Peta Sumber dan Bahaya Gempa Indonesia Tahun 2017 Pusat Penelitian dan Pengembangan Perumahan dan Pemukiman Badan Penelitian dan Pengembangan Kementrian Pekerjaan Umum dan Perumahan Rakyat,. 
Wulandari, A., Suharno, S. dan Rustadi, R. (2018), "Pemetaan Mikrozonasi Daerah Rawan Gempabumi Menggunakan Metode HVSR Daerah Painan Sumatera Barat", Jurnal Geofisika Eksplorasi, Vol.4, No.1, hal. 31-45. http://doi.org/10.23960/jge.v4i1.5. 